\title{
Innovative Application of Quality Education in Ideological and Political Work of College Students
}

\author{
Yaxiu Liu \\ School of Electronic and Information Engineering, North China Institute of Science and Technology, Yanjiao \\ Development Zone, Sanhe County, 065201, china \\ liuyaxiu1975@ncist.edu.cn
}

\begin{abstract}
He author analyzed the role of quality education in college students' ideological and political work, pointed out that both of them penetrate, connect, promote and coordinatedly develop mutually, and quality education can be innovatively applied in the ideological and political work. At the same time, basing own work experience, the author put forward some concrete measures to carry out quality education: for students in grade one, to set good habits and new goals; for students in grade two, to conduct innovation consciousness education; for those in grade three, to set appropriate objectives; and for those in grade four, to conduct employment, graduate education. Finally, the author pointed out that the key points of quality education include that the educators should make full use of their own conditions, cultivate the practical ability and strengthen the teacher's learning.
\end{abstract}

Index Terms - Political Work, Quality Education, Innovative, Ideological.

\section{I . Introduction}

In recent years, the basic quality of the society of college students put forward higher requirements, but now many students in this regard is still a considerable gap exists, it is also an important cause of the current college students employment difficulty.

In addition, in the development of the world towards multi-polarization, the development of all countries present influence each other, learn from each other, learn from each other 's trend, the competition between countries is becoming increasingly fierce competition in the final analysis, which, for the competition of high quality talent. From a macro point of view, the college students' basic quality will affect the development of the whole country.

Based on the above reasons, we urgently need to strengthen the quality education of college students at present.

What is the quality education? In 2001 June, the CPC Central Committee and State Council "on the points out that deepening education reform and promoting quality education" : "the implementation of quality education is to fully implement the party's education policy, to improve the quality of the people as the fundamental purpose, to cultivate students' innovative spirit and practical ability as the key point, create ideals, morality, culture, comprehensive development of socialist builders and successors. "

Effect of quality education in college students' Ideological and political work in the quality education is a new education mode, the goal is to improve the basic ability of college students, including the moral quality, professional skills, physical and mental health. The ideological and political work is the health of the entire education development security, quality education and conducive to the ideological and political work.

On the whole, the quality of education in the ideological and political work is mainly manifested in the following aspects:

The quality education and ideological and political work to infiltrate each other, related to each other, mutual promotion, collaborative development. On the one hand, the purpose of quality education is to cultivate a sound personality, both theoretical knowledge and practical ability, knowledge of both the depth and the breadth, appropriate with innovative consciousness and innovative ability of comprehensive development, the healthy development of the talent. Ideological and political work plays an irreplaceable role in the process of quality education, it is the quality of education to ensure the success. On the other hand, the ideological and political quality is the foundation of quality education and the organic component. Therefore, the effect of Ideological and political work has play a decisive role role in the quality education, ideological and political work is the basis of quality education. At the same time, quality education may ensure the smooth development of ideological and political work.

The quality education may innovate the College Ideological and political work

The object of quality education includes not only the education, including education. To complete the mission of quality education, the educator himself first needs to carry on the comprehensive quality education on its own: first itself has a healthy personality, excellent ideological and political quality, theory and practice, has innovation consciousness and innovation ability, etc. Therefore, the education of Ideological and political work for college students, compared with the past, many innovations will naturally arise, including education philosophy, education mode, education methods. No doubt, it will greatly ensure the effect of Ideological and political work.

\section{II . College students' quality education practice}

The following is the author practice in actual work:

To the students in Grade One, to educate them to study 
habits and set new goals of education. Focus on a computer and English four levels of levels of occupation career planning, design, professional education, learning methods and learning goals, the selection and establishment of important basic course supervision etc.. Three misunderstandings existed freshmen thinking: one is today finally admitted to the University, can relax; two is in the safe; three are in the school only to learn to do a good job on the line, walk the one step that one step.

Therefore the quality education for students should know from the beginning of torsion freshman thought, and how to adapt to the new university life as the basis, to tell the students to establish correct occupation ideal, want to take the personal ambition and the interests of the state and social demand organically. Only the choice of ideal occupation, will accordingly as the goal, to plan his study and practice; secondly to determine career goals ( short-term and long-term goals ), namely oneself intended to be where the talent, to which fields become. These problems can not be clearly will directly affect the individual 's chances of success. For the freshman, the first year, is mainly concerned about the employment situation, to prepare for future employment, so ask the students to learn each course, and make full use of resources to the school library and computer room, reinforce the learning base, and advocates a to find temporary jobs in the summer. In addition, through school education, choose learning methods, and establish learning goals and guide the students' occupation career planning, to encourage students to actively move closer to the party organizations and other ways to penetrate the current employment situation, the unit 's request, the ideal high-quality graduates should have the conditions and other information, so that students from the school it has the employment consciousness and correct political pursuit, and the professional training objectives, employment prospects to understand consciously, so as to make the learning and practice of more targeted.

For the second grade students, education focuses on the innovative consciousness and innovative personality. Focus on the occupation consciousness training guidance, practice training, exercise, activities of science and technology communication courses of training, learning, stylistic quality training etc. Firstly, to guide the students to do self-analysis. Very important to own understanding and positioning, only know their own interests, strengths, weaknesses and strengths, to avoid weaknesses, make their own " bright spot " more prominent. To constantly encourage students according to their own characteristics to participate in the innovation practice or take part in some competitions, to continue to strengthen their sense of innovation, the development of creative personality; secondly, to guide students through the correct analysis of occupation, don't just look at the unit size and reputation, it is better to know its concern about the development status and development future occupation of the industry, understand the different requirements for applicants of different occupation post, so as to develop their creative personality, cultivate their innovative ability, which is more conducive to the realization of the ideal goal. Specific ways including not regularly invite in electronic design contest, all kinds of knowledge competition and entrepreneurship competition award-winning students give the big two students do experience and learning, design, practice and other aspects of the guidance, arouse students enthusiasm; encourage students to use their spare time as much as possible into the innovation laboratory, independent study and experiment to improve the discovery problem, the ability to analyze and solve problems; students are required to pay enough attention to the practice teaching such as the curriculum design, experiment and practice; when necessary, to attend some professional skills training, vocational skills training.

The third grade to the goals established education. Focus on examination goal guidance, employment skills, training, psychological counseling, curriculum design and related experiments, practice, training etc.. Guide the students according to their own situation clearly Kaoyan or employment target ( a few study abroad ). According to the different target focus to strengthen, recharging. For students, should focus on from the formation of professional choice intention, determine the examination unit, obtain test information, review of the notes, condition adjustment guidance. For after graduation employment of students, mainly to help them understand social needs, obtain employment unit information, hold to the unit training or internship opportunity. Focus on the job search skills learning and training. Encourage students to enter the job market to find a job, to feel the pressure of employment. The forms included invited inside and outside talent, especially the industry elite and excellent alumni for higher education and employment of the lectures and exchange of experience; pay attention to practice teaching ( such as production practice and course design ), the individual student's individual counseling and etc..

The fourth grade to graduate, employment, graduate of education. Including career professional curriculum design, concept, skill education, preparation for postgraduate examination guidance, psychological counseling, graduation design and graduation civilization safety education. For a few select PubMed students: continue to pay attention to its review of the notes of the previous successful students, written examination and interview skills and experience, and the problems to solve. In 2011 the graduate admission work, 07 grade 3 students were admitted by Zhejiang University 985 well-known colleges and universities, Huazhong University of Science and Technology and the University of Electronic Science and technology. For the vast majority of students choose employment: the main guide its full understanding of the situation, the reasonable expectations of employment adjustment, early active employment, employment, employment first selection, can choose to the grass-roots employment or self-employment, abandon the " and so on, to" ideas, establish " line may be meritorious, everywhere to businesses, labor the most glorious " employment outlook. Guide the student to write a cover letter and resume, job search and interview skills on the essentials, and focus on the 
employment situation and policies of the propaganda and education. Introduction previous graduates of the experience and lessons, special education students should be honest and trustworthy, fair competition. Provide as much employment information for students. In addition to the above, we also especially in education, study abroad, employment, entrepreneurship and other different to the process because of the pressure is too large, and all kinds of problem students patience communication and guidance.

\section{III . Several key points in quality education}

The first one is to make full use of their own conditions. Our school has a good educational environment, abundant teaching resources, teaching faculty. The teaching resources, such as institute library literature and digital resources complementary multiple types, multiple carriers, comprehensive, multi-functional modern intelligent library. In addition, the computer room, laboratory, especially the Innovation Lab also provides the possibility for the quality of high quality education, but also has become the students to learn new knowledge, to display their talents into place. They seemed to have a big classroom outside the classroom, students can use the good atmosphere there, keep the good study habits, broaden their knowledge, enhance access to knowledge and information skills.

The second one is the practical ability training. In their daily work, guide and encourage more students to participate in school activities consciously, these activities include the learning aspects, such as scientific research training, science and technology innovation activities, teaching practice and scientific and technological competitions, including style, such as literature and art performances, sports competitions, as well as social practice activities, such as social investigation, " three to the countryside ", work-study, through personal experience, to improve the practical ability, communication skills, teamwork spirit.

To strengthen the teacher's learning, improve the standard of education. School education is the position, the teacher is the school 's " soul ", our department teachers, young teachers accounted for the vast majority of young teachers, students and youth similar in age, psychological gap small, ideology, lifestyle, affect its value orientation and political thought of the young students are more significant, so young teachers' political quality must be strengthened. Secondly, combined with the need of the work, continue to enhance mutual understanding and Research on professional knowledge, employment guidance, psychology and human relations, and strive to " double teacher type " or even " teacher" talents forward, enhance service awareness, to highlight the leading role, and construct a better platform for high quality education.

\section{IV . Conclusion}

It had been proved that the working practice of a few years, quality education can promote the all-round development of students, help students' employment, maintain stable thought of College students. Quality education could improve the students' comprehensive quality, enhance the chances of acceptance of their employment skills and be unit; at the same time, some students but also because of the science and technology innovation and competition of outstanding performance, in a job or graduate admission competition in the talent showing itself, and the students to become entrepreneurs. These results further stimulate students learning enthusiasm, maintain ideological and stability.

\section{References}

[1] Zuo Huiqin. " Student-oriented " from the perspective of the university campus environment construction of ideological political education . Jilin University, 2008

[2] Liu Hui . People-oriented ideological and political education of college students concept and . Soochow University, 2008

[3] Liu Wenting. Ideological and political education of the thought of "people-oriented" in study of . Guizhou University, 2010

[4] Hao Shaohua. On the ideological and political education in the "peopleoriented ". Xi'an University of Science And Technology, 2010

[5] Yang Chongze . People-oriented ideological and political education in the application . Journal of Anshun University, 2008, ( 03 ).

[6] Peng Xuegui, Huang Lingjuan. Discussion on " people-oriented " to strengthen the ideological and political education of college students . the vicissitudes of life, 2008, ( 01 ).

[7] Li Ruimin. The innovation of Ideological and political education of university students' . Journal of Hubei Correspondence University, 2008, ( 04 ).

[8] Huang Xueya. Moral education in secondary vocational schools should adhere to the people-oriented. Journal of Fujian Institute of Education (2009, 04 )

[9] Zhu Sha, Song Yatao. Discussion on College Students' Ideological and political work should be people-oriented approach ( Theory ), history 2008, ( 09 ) 